\title{
KONSTRUKSI MAKNA INFORMASI RISIKO PENYAKIT BAGI PENYANDANG FILARIASIS
}

\author{
Purwanti Hadisiwi \\ Fakultas Komunikasi, Universitas Padjadjaran Bandung, Jatinangor Jawa Barat \\ Telp/Fax/HP (022) 2014448/08122326908, email hadisiwi@yahoo.com \\ Naskah dikirim tanggal 19 Januari 2012 disetujui 15 April 2012
}

\section{MEANING CONSTRUCTION OF RISK INFORMATION DISEASE BY PERSONS WITH FILARIASIS}

\begin{abstract}
Information about filariasis was part of health risk communication which might result in negative impact if not managed in accordance with the principles of risk communication; interactive, involving other credible parties, accurate, honest, with a scientific explanation. The study used qualitative method with phenomenological approach aimed to determine the meaning of filariasis information from various sources, which were constructed by persons with filariasis in Bandung Regency. Involving 10 persons with filariasis whom were selected purposively, the study revealed that the information conveyed directly by a doctor at the health center with data and pictures, was perceived as trusted, whereas one way communication, mentioning inaccurately the name of disease, or even did not name the disease, were perceived as confusing.
\end{abstract}

Keywords: construction of meaning, the physically filariasis, risk communication, risk information.

\begin{abstract}
Abstrak
Informasi mengenai filariasis adalah bagian dari komunikasi risiko kesehatan yang dapat berdampak negatif jika tidak dikelola sesuai dengan prinsip-prinsip komunikasi risiko yaitu, interaktif, melibatkan pihak-pihak lain yang kredibel, akurat, jujur, dengan penjelasan yang ilmiah. Penelitian menggunakan metode kualitatif dengan pendekatan fenomenologi ini bertujuan untuk mengetahui makna informasi filariasis dari berbagai sumber, yang dikonstruksi oleh penyandang filariasis di Kabupaten Bandung. Melalui informan penelitian yang berjumlah 10 penyandang filariasis yang ditentukan secara purposif, terungkap bahwa informasi yang disampaikan langsung oleh dokter di Puskesmas dengan data dan gambar yang jelas, dimaknai dengan terpercaya, sedangkan informasi yang searah, penyebutan nama penyakit yang tidak akurat tidak menyebutkan nama penyakit, dimaknai sebagai membingungkan.
\end{abstract}

Kata Kunci: Konstruksi makna, penyandang filariasis, komunikasi risiko, informasi risiko

\section{PENDAHULUAN}

Pada akhir 2009, masyarakat dikejutkan dengan informasi tentang tewasnya sembilan warga Kabupaten Bandung yang diduga akibat pengobatan massal filariasis. Peristiwa itu selain memunculkan pertanyaan tentang pengobatan massal yang tidak sesuai 
prosedur, juga menyadarkan banyak pihak mengenai adanya penyakit endemik filariasis dan keberadaan penyandang filariasis di Kabupaten Bandung. Filariasis adalah salah satu dari penyakit endemik yang disebabkan oleh cacing filaria yang ditularkan oleh berbagai jenis nyamuk. Di masyarakat nama penyakit ini dikenal dengan istilah penyakit "kaki gajah". Walaupun filariasis tidak menyebabkan kematian, pada stadium lanjut penyakit ini dapat menimbulkan cacat seumur hidup berupa pembengkakan pada kaki, lengan, payudara, dan alat kelamin.

Penyandang filariasis di Kabupaten Bandung yang terdata pada 2007 berjumlah 31 orang, namun pada 2010 telah meninggal dunia 2 orang sehingga menjadi 29 orang. Mereka tersebar di 13 Kecamatan yang membentang dari wilayah Kabupaten Bandung bagian Timur sampai ke wilayah bagian Barat.

Penyandang filariasis yang rata-rata sudah mengalami cacat bengkak sedikitnya selama 10 tahun, menjalani pengobatan tanpa petunjuk yang jelas, baik mengenai informasi penyakit, penamaan penyakit yang didapatnya dari petugas kesehatan, perawatan sakit dan pengobatannya. Padahal penyakit ini secara kasat mata dapat dikenali sehingga dapat diberikan informasi pengobatan dan perawatannya. Kurangnya perhatian disebabkan oleh keberadaannya yang sulit dijangkau atau karena tidak terlibat dalam aktivitas ekonomi maupun sosial. Seperti yang dinyatakan oleh Dirjen WHO bahwa filariasis adalah penyakit parasitik yang termasuk ke dalam neglected disease, dan merupakan penyakit tersembunyi atau silent disease, karena hanya ditemukan di daerah perdesaan, penderitanya tidak pernah keluar rumah sehingga tidak terpantau petugas kesehatan. Dengan demikian informasi mengenai penyakit filariasis yang diterima oleh penyandang flariasis pun menjadi sangat terbatas.

Masyarakat dan penyandang filariasis di daerah endemis memerlukan informasi yang benar dan tepat sasaran mengenai penyakit yang mengakibatkan cacat ini. Diperlukan informasi yang terpadu dari Kementerian
Kesehatan, aparat pemerintahan setempat, dan lembaga-lembaga terkait lainnya. Penyebar luasan informasi harus dalam konteks interaksi yang memungkinkan dialog dari pihak-pihak yang berkepentingan sehingga tidak memunculkan pemahaman yang berbeda-beda pada pihak yang menjadi target sasaran informasi.

Tindakan menyampaikan informasi yang berhubungan dengan risiko kesehatan disebut komunikasi risiko, seperti yang dinyatakan oleh Powell dan William Leiss (2001) bahwa risk communication is the process of exchanges about how best to assess and manage risks among academics, regulatory practitioners, interest groups, and general public. Pengelolaan komunikasi risiko yang kurang baik dalam program pengobatan massal mengakibatkan peristiwa tewasnya sembilan orang warga seperti yang dikutip di awal tulisan. Tewasnya warga disebabkan oleh ketidak jelasan informasi mengenai pengecualian untuk tidak mendapatkan pengobatan massal bagi warga yang menderita penyakit jantung, darah tinggi, diabetes. Ketidakjelasan informasi yang diterima warga khususnya penyandang filariasis tidak saja dialami pada saat pengobatan massal, namun sejak mereka terjangkit filariasis. Informasi tentang filariasis, baik dari nama penyakit, pencegahan, pengobatan, perawatan dan risiko cacat yang diterima oleh penyandang filariasis telah memberi gambaran bahwa komunikasi risiko belum dipahami secara benar oleh pihak-pihak terkait. Berdasarkan uraian tersebut penulis merumuskan penelitian, "Bagaimana konstruksi makna informasi risiko penyakit bagi penyandang filariasis ?". Adapun tujuan penelitian ini adalah untuk menemukan penjelasan makna informasi risiko filariasis yang diperoleh dari dokter, untuk menemukan penjelasan makna informasi nama penyakit filariasis yang diperoleh dari dokter, untuk menemukan makna informasi filariasis dari media massa.

Penelitian ini diharapkan dapat memberi kontribusi bagi pemerintah khususnya Kementerian Kesehatan dari tingkat pusat sampai daerah untuk dapat memahami konsep komunikasi risiko 
kesehatan. Pemahaman pemerintah dan pihak-pihak yang terkait dengan komunikasi risiko kesehatan diharapkan dapat menjadikan hasil penelitian ini sebagai referensi dalam menyempurnakan tindakan komunikasi risiko kesehatan pada masyarakat, khususnya dalam menyosialisasikan informasi tentang pengobatan massal dan perhatian yang lebih terhadap penyandang filariasis.

\section{LANDASAN KONSEP}

\section{Komunikasi Risiko}

Komunikasi risiko pada awalnya
banyak digunakan berkenaan dengan
risiko/bahaya lingkungan, namun kemudian berkembang ke bidang kesehatan dan isu-isu sosial lainnya. Kegagalan komunikasi risiko pada waktu lalu, seringkali mengakibatkan terjadinya kekhawatiran publik menjadi konflik yang berlarut-larut antara masyarakat, industri, pemerintah bahkan para akademisi atau ahli. Kajian komunikasi risiko muncul sebagai jawaban atas kebutuhan adanya hubungan dan dialog antara pemerintah, industri, dan akademisi dengan masyarakat. Hubungan dan dialog diperlukan untuk mengurangi masalah mendasar yang sangat dilematis yang menjadi perhatian bersama yaitu bagaimana menghadapi isu berkenaan dengan risiko pencemaran lingkungan, makanan yang terkontaminasi, wabah penyakit, dan lain-lain.

Menurut Covello (1986) Risk communication is the act of conveying or transmitting information between parties about (a) levels of health or environmental risks; (b) the significance or meaning of health or environmental risks; or (c) decisions, actions, or policies aimed at managing or controlling health or environmental risks. (komunikasi risiko adalah kegiatan menyampaikan informasi diantara pihak-pihak yang terlibat tentang a) tingkat risiko kesehatan atau lingkungan, b) pemaknaan risiko kesehatan dan lingkungan, c) keputusan, kegiatan atau kebijakan yang ditujukan untuk mengelola dan mengontrol risiko kesehatan atau lingkungan). Pihak- pihak yang terlibat, menurut Covello adalah lembaga-lembaga pemerintah, perusahaan dan industri, media, ilmuwan, organisasi profesi, kelompok-kelompok pemerhati, dan masyarakat.

Sedangkan National Research Council dalam Sellnow, dkk (2009) menyatakan bahwa, risk communication can be defined as the interactive process of exchange of information and opinion among individuals, group, and institutions. It involves multiple messages about the nature of risk and other messages, not strictly about risk, that express concerns, opinions, or reaction to legal or institutional arranggements for risk management. (komunikasi risiko dapat didefinisikan sebagai proses interaksi dari pertukaran informasi dan opini diantara individu, kelompok dan lembaga yang meliputi banyak pesan tentang risiko dan pesan lainnya, tidak secara tegas tentang risiko, yang mengekspresikan kepedulian, opini atau reaksi terhadap pengaturan resmi dan kelembagaan untuk manajemen risiko) (Sellnow, dkk, 2009).

Dari kedua definisi di atas dapat disimpulkan bahwa komunikasi risiko adalah proses pertukaran informasi yang mengekspresikan kepedulian, opini atau reaksi terhadap pesan-pesan risiko atau terhadap penjelasan-penjelasan resmi manajemen risiko diantara para ahli, pemerintah, industri, media massa, dan masyarakat. Pihak-pihak yang terkait sebaiknya dapat menilai dan mengelola risiko secara bersama-sama yang menunjukkan adanya proses interaksi yang positif. Dijelaskan oleh Sellnow, dkk (2009) bahwa tujuan akhir dari komunikasi risiko adalah untuk mencegah krisis. Krisis terjadi ketika kita tidak dapat melakukan tindakan yang tepat atau gagal mengidentifikasi risiko. Krisis adalah situasi manakala malapetaka atau bencana menyebabkan kondisi bahaya. Oleh karena itu komunikasi risiko dilakukan untuk mengantisipasi segala kemungkinan bahaya dengan upaya untuk mengurangi kemungkinan terjadinya krisis dalam jangka waktu yang panjang. 


\section{Komunikasi Kesehatan}

Komunikasi kesehatan didefinisikan dengan beragam sesuai dengan tujuan yang ingin dicapai dalam proses komunikasinya. Tujuan komunikasi kesehatan untuk memberi informasi dan memengaruhi keputusan individu atau komunitas, terlihat dalam definisi yang diberikan oleh New South Wales Department of Health, Australia: "Health communication is a key strategy to inform the public about health concerns and to maintain important health issues on the public agenda" (Schiavo,2007). Sedangkan definisi komunikasi kesehatan yang lain bertujuan untuk merubah perilaku dapat dilihat dari definisi yang disampaikan oleh Clift dan Freimuth dalam Sciavo bahwa "health communication, like health education, is an approach which attempts to change a set of behaviors in a large scale target audience regarding a specific problem in a predefined period of time" (2007). Definisi-definisi di atas menggambarkan bagaimana isu kesehatan diinformasikan untuk dapat memengaruhi keputusan dan mengubah perilaku individu atau komuniti. Dalam definisi tersebut tidak dijelaskan kesehatan sebagai sebuah konsep yang juga harus dipahami secara luas.

Kesehatan sebagai sebuah konsep telah didefinisikan dengan berbeda-beda secara lintas budaya di seluruh dunia. Perbedaan ini disebabkan oleh cara pandang terhadap gejala sakit dan pengaruhnya terhadap perilaku sehat, pencegahan sakit, dan pengobatannya. Cara pandang yang berbeda tentang kesehatan dan keadaan sakit berhubungan dengan budaya, agama, suku/etnis, nilai, kepercayaan, keadaan sosial dan ekonomi serta masalah gender. Menurut Sciavo (2007) setidaknya ada dua model untuk mendefinisikan kesehatan, yaitu model biomedis yang hanya memandang keadaan sehat atau sakit secara fisik saja. Faktor-faktor lain sebagai penyebab sakit, seperti faktor psikologis, kepercayaan, sikap, norma sosial, tradisi dan gaya hidup diabaikan oleh model ini. Sebagai akibatnya upaya-upaya komunikasi kesehatan yang dilakukan cenderung informatif, sangat ilmiah, indoktrinasi, efisien, dan terfokus pada pendekatan komunikasi top-down yang membatasi penyampaian isu-isu kesehatan dan penanggulangan masalahnya. Model ini kurang berempati terhadap perasaan dan pengalaman sosial pasien (Fredman dan Di Matteo dalam Sciavo, 2007). Padahal diketahui bahwa banyak penyakit sekarang ini sangat dipengaruhi oleh kebiasaan sosial, budaya dan kondisi psikologis. Sedangkan model biopsikososial memandang bahwa kesehatan yang buruk bukan hanya fenomena fisik tetapi juga kondisi perasaan atau psikologis, anggapan tentang sakit dan peristiwa yang terjadi pada seseorang. Model ini menekankan pada pendekatan yang berfokus pada pasien. Model yang cenderung menekankan pada komunikasi empatik ini sekarang banyak diterapkan sebagai pengganti model biomedis. Konsep keseimbangan ini dianggap telah mewakili banyak penduduk dunia dengan budayanya yang berbeda-beda.

Komunikasi kesehatan menyangkut bagaimana manusia bereaksi ketika berhadapan dengan masalah yang berhubungan dengan kesehatan. Dalam komunikasi kesehatan, fokusnya adalah pertukaran informasi secara spesifik dan faktor-faktor yang memengaruhi proses pertukaran informasi ini (Pettegrew, 1982). Pertukaran informasi dapat terjadi secara verbal atau nonverbal, oral atau tertulis, personal atau impersonal. Secara umum komunikasi kesehatan merupakan aplikasi dari konsep dan teori komunikasi dalam proses pertukaran informasi yang muncul mengenai masalah yang menyangkut tentang kesehatan.

Dalam prosesnya, komunikasi kesehatan antara pasien dan pihak medis seringkali mengalami hambatan, seperti yang dibahas oleh Sciavo (2010) meliputi tingkat pendidikan, tingkat literasi kesehatan, bahasa, perbedaan budaya, usia, keterbatasan kognisi, jargon kesehatan yang sulit dipahami, penyakit akibat stres dan ketidakseimbangan kekuatan (power). Tingkat pendidikan pasien yang rendah berimplikasi pada kemampuan komunikasi verbal (bahasa). Dengan keterbatasan berbahasa, ditambah dengan 
keterbatasan waktu yang tersedia ketika berkomunikasi dengan pihak medis, membuat pasien tidak dapat mengembangkan keterampilannya dalam pertukaran informasi, yaitu pencarian informasi, penetapan informasi dan pengujian informasi (Cegala dan Broz, dalamThompson dkk 2003). Proses pencarian informasi ditunjukkan pasien dengan pengetahuannya tentang penyakit, kemampuannya mempersiapkan pertanyaan dan kemampuannya bertanya secara spontan selama konsultasi dengan pihak medis. Sedangkan penetapan informasi ditunjukkan pasien dengan kemampuan mengekspresikan permasalahan kesehatannya atau dengan menyampaikan gejala sakit dengan jelas dan lengkap. Mengklarifikasi atau menguji informasi dilakukan dengan menyampaikan pertanyaan-pertanyaan dan melakukan pengulangan dari pernyataanpernyataan yang disampaikan oleh pihak medis.

Literasi kesehatan oleh The American Medical Association yang mewakili model biomedis didefinisikan sebagai kemampuan membaca dan memahami resep obat, kartu berobat, dan bentuk materi lainnya yang berhubungan dengan peran dirinya sebagai pasien. Sedangkan WHO yang mengarah pada model biopsikososial mendefinisikan literasi kesehatan sebagai keterampilan kognisi dan sosial yang menentukan motivasi dan kemampuan individu untuk mengakses, memahami dan menggunakan informasi sebagai cara untuk meningkatkan dan menjaga kesehatannya. Literasi kesehatan yang rendah merupakan salah satu dari hambatan komunikasi pihak medis dan pasien yang berdampak pada meningkatnya rasa malu pasien, menurunkan tingkat pengetahuan kesehatan, perilaku kesehatan yang buruk dan tidak mematuhi pengobatan sehingga meningkatkan biaya pengobatan individu maupun masyarakat.(Thompson dkk, 2003).

\section{Interaksi Simbolik}

Esensi dari interaksi simbolik adalah suatu aktivitas yang merupakan ciri khas manusia, yakni komunikasi atau pertukaran simbol yang diberi makna (Mulyana, 2004). Banyak ahli di belakang perspektif ini yang mengatakan bahwa individu sebagai manusia merupakan hal yang paling penting. Mereka mengatakan bahwa individu adalah objek yang bisa secara langsung ditelaah dan dianalisis melalui interaksinya dengan individu yang lain. Menurut Ralph Larossa dan Donald C. Reitzes (1993) interaksi simbolik pada intinya menjelaskan tentang kerangka referensi untuk memahami bagaimana manusia, bersama dengan orang lain, menciptakan dunia simbolik dan bagaimana cara dunia membentuk perilaku manusia. Interaksi simbolik ada karena ideide dasar dalam membentuk makna yang berasal dari pikiran manusia (Mind) mengenai diri (Self), dan hubungannya di tengah interaksi sosial, dan tujuan akhir untuk memediasi, serta menginterpretasi makna di tengah masyarakat (Society) dimana individu tersebut menetap.

Menurut Mead, adalah penting untuk mengakui peranan utama simbol bagi individu. Simbol, khususnya bahasa, merubah manusia dari kelemahan, kebodohan, dan organisma yang lemah, menjadi suatu makhluk yang kompleks, fleksibel, dan cerdas dengan keunikan alamiahnya. Simbol adalah suatu rangsangan yang mengandung makna dan nilai yang dipelajari bagi manusia, dan respon manusia terhadap simbol adalah dalam pengertian makna dan nilainya, alih-alih dalam pengertian stimulasi fisik dari alat inderanya. (Mulyana, 2004). Menurut Charon (2007) melalui penggunaan simbol bahasa, manusia dapat melakukan hal-hal seperti, memberi nama manusia, mengingat, membuat kategori, merasa, berpikir, berunding, memecahkan masalah, menembus ruang dan waktu, masuk kedalam diri dan orang lain, menciptakan abstraksi, menciptakan ide-ide baru, dan mengarahkan diri sendiri.

Aktivitas individu dalam menggunakan simbol atau bahasa dilakukannya melalui interaksi dengan masyarakat. Hasil aktivitas individu ini akan berpengaruh pada masyarakat tempat individu tersebut berinteraksi. Hubungan antara masyarakat dan individu yang berinteraksi menggunakan simbol-simbol yang sama, akan 
mereka maknai sesuai dengan interaksi mereka tersebut. Interaksi menggunakan simbol yang sama dalam suatu masyarakat ini dapat membentuk konstruksi realitas sosial bagi individu yang terlibat di dalamnya.

Simbolisme suatu makna bukan hanya bahasa, simbolisme adalah semua aspek tindakan manusia. Hal ini bukanlah ide baru, tetapi bahasa telah sangat diistimewakan dalam karya-karya para ahli interaksi simbolik. Interaksi simbolik memungkinkan manusia untuk memahami realitas dan berinteraksi dengan manusia lain dalam suatu proses komunikasi, dalam arti pesan yang dimaknai dan ditransformasikan pada pihak lain pada akhirnya dapat memengaruhi pihak kedua dalam suatu proses komunikasi yang timbal balik. Menurut Blumer, makna yang diciptakan individu merupakan pusat dari kehidupan manusia bukan hanya sebagai sesuatu yang taken for granted dan kemudian disingkirkan sebagai sesuatu yang tidak penting karena hanya dianggap sebagai sarana bagi pembentukan perilaku.

\section{METODE PENELITIAN}

Penelitian ini menggunakan metode kualitatif dengan pendekatan fenomenologi dengan melihat realitas apa adanya yang salah satu variannya adalah interaksionisme simbolik. Menurut Littlejohn Phenomenology means letting things become manifest as what they are, without forcing our own categories on them. (2004) Oleh karena itu realitas yang muncul menjadi tidak terbatas kecuali melihat realitas itu dalam bingkai batasan-batasan yang telah ditetapkan.

Informan penelitian penyandang filariasis berjumlah 29 orang, peneliti menentukan secara purposif sebanyak 10 orang sesuai dengan pendapat Creswell (1998), interview with up to 10 people, berdasarkan tempat tinggalnya, jenis cacatnya, jenis kelaminnya, usianya, dan lamanya menyandang firariasis dan stadium kecacatan penyandang filariasis. Mereka adalah Dariah (53 thn) Kecamatan Margaasih , Elon (60 thn) Kecamatan Paseh , Idah (65 thn) Kecamatan Paseh, Lia Natalia
(18 thn) Kecamatan Banjaran, Ai Suryani (33 thn) Kecamatan Majalaya, Anih (39 thn) Kecamatan Baleendah, Aam Nasrulloh (14 thn) Kecamatan Ibun, D.Tarmiji (70 thn) Kecamatan Kutawaringin, Siti Hasanah (42 thn) Kecamatan Soreang, O.Kardi (70 thn) Kecamatan Soreang.

Pengumpulan data dalam penelitian ini dilakukan melalui wawancara mendalam, Observasi partisipatif dan analisis dokumen. Lokasi penelitian di Kabupaten Bandung

\section{HASIL PENELITIAN DAN PEMBAHASAN}

\section{Makna Informasi Risiko Filariasis Yang Berasal Dari Dokter}

Bagi penyandang filariasis, informasi yang berhubungan dengan penyakitnya menjadi sesuatu hal yang sangat penting. Informasi tentang filariasis bisa jadi dapat mengurangi ketidakpastian mengenai penyakit ini. Informasi tentang filariasis dapat dikategorikan ke dalam informasi risiko karena dapat berdampak besar bagi kesehatan dan kelangsungan hidup penyandangnya dan orang-orang yang berada dalam lingkungan yang berisiko tinggi tertular. Informasi yang tidak tepat dan jelas akan sangat membingungkan dan menyesatkan yang berakibat pada memburuknya kondisi fisik dan psikis penyandang filariasis.

Informasi yang diperoleh penyandang filariasis sebelum adanya pengobatan massal sangat terbatas, yaitu hanya dari dokter atau petugas kesehatan di Puskesmas. Informasi yang diperoleh melalui interaksinya dengan dokter dan petugas kesehatan telah dimaknai dengan positif oleh beberapa penyandang filariasis. Informasi yang dimaknai "lebih bisa" dipercaya adalah informasi yang dijelaskan oleh dokter dengan bukti-bukti langsung berupa penjelasan melalui gambar siklus penularan, dan gambar-gambar tentang penyandang filariasis. Dokter adalah orang yang kredibilitasnya dalam bidang kesehatan dinilai pasien sangat tinggi. Dengan keahlian yang dimilikinya, informasi yang 
disampaikan kepada pasiennya akan lebih dapat diterima dibandingkan informasi yang diterimanya melalui media massa. Hal ini sesuai dengan hasil penelitian mengenai penyebaran informasi mengenai antrax dan penyakit cacar air di Amerika yang menyatakan bahwa the public prefers its information directly from a known and trusted source (Andersen dan Spitzberg, dalam Heath dan O'Hair, 2009).

Pemaknaan yang positif mengenai informasi dari dokter adalah produk interaksi sosial, yaitu ketika makna dinegosiasikan melalui penggunaan bahasa berdasarkan situasi dimana objek fisik yang berupa bangunan, ruang periksa dan segala asesoris yang menjadi atribut seorang dokter dan objek sosial seperti penerimaan dan cara bertutur dokter yang ramah direspon secara positif. Dalam komunikasi risiko kesehatan, perlu diperhatikan the need for information about risks to be communicated in an accurate, honest and even frank manner (Selnoww dkk, 2009). Selain penyampaian informasi yang akurat, tulus dan jujur, menurut National Cancer Institute and National Institute of Health USA, informasi kesehatan harus mempertimbangkan beberapa hal berikut ini:

a. Singkat dan to the point, yaitu bahwa pesan harus singkat supaya tidak membingungkan.

b. Kredibel, yaitu memanfaatkan bukti dan pembicara yang bereputasi.

c. Relevan dengan khalayaknya, yaitu sesuai dengan kepentingan khalayak.

d. Konsisten, yaitu kesesuaian antara materi dan waktu yang tersedia.

e. Sederhana, yaitu tidak menggunakan jargon atau terminologi yang teknis.

f. Mudah diingat, yaitu dengan menggunakan bahasa yang mudah diingat. (Sciavo, 2007).

Namun demikian, makna informasi dari dokter yang dinilai positif ini sering dikaburkan dengan informasi dari sumber lain yang juga dipercayainya. Ketidakajegan dalam memaknai informasi dari dokter dan petugas Puskesmas disebabkan oleh lamanya proses pencarian informasi mengenai penyakit yang memakan waktu bertahuntahun tanpa kepastian kesembuhan. Menurut Mulyana (2004), ketika mereka (penyandang filariasis) menghadapi suatu situasi, respon mereka tidak bersifat mekanis, tidak pula ditentukan oleh faktor-faktor eksternal; alihalih, respon mereka tergantung pada bagaimana mereka mendefinisikan situasi yang dihadapi dalam interaksi sosial . Sementara itu interaksi sosial adalah sebuah proses yang berkelanjutan yang dialami penyandang filariasis sesuai dengan intensitasnya masing-masing. Dengan demikian informasi filariasis sebagai sebuah realitas diberi makna yang berubah-ubah melalui proses sosial yang berbeda-beda. Lebih jauh mengenai pemahaman dan pemaknaan tentang risiko yang diproduksi melalui proses sosial dikemukakan oleh Sellnow, Ulmer, Seeger dan Littlefield (2009) sbb: “. ... as information is created and disseminated about risks, their meaning changes: perceptions of risk may be amplified by social interaction, cultural practices, or the mass media. Age and gender have been shown to impact perception of risk. Personal experiences and memories may change the meaning of a particular factor".

Informasi dari dokter ada juga yang dimaknai oleh penyandang filariasis sebagai menakut-nakuti. Komunikasi risiko kesehatan yang terjadi antara dokter dan penyandang filariasis yang masih anak-anak, menggambarkan ketidakseimbangan hubungan ditinjau dari berbagai aspek. Dokter yang berperan sebagai ahli penyakit cenderung menyampaikan informasi dengan berlebihan atau sebaliknya menganggap enteng penyakit, seperti pendapat Covello dan Johnson dalam Sellnow, dkk (2009) bahwa risks are exaggerated or minimized according to the social, cultural and moral acceptability of various activities. Informasi yang diterima dari dokter, yaitu harus dioperasi atau harus diamputasi karena jika tidak dioperasi akan membengkak sangat besar, dinggap semacam ancaman yang telah dinegosiasikan dengan kata "nyingsieunan" (menakut-nakuti) oleh penyandang filariasis yang masih kanakkanak.

Informasi dari dokter ada juga yang 


\section{Tabel 1}

\section{Hasil Penelitian Di Amerika Mengenai Berpindahnya Pasien Ke Dokter Lain Karena Ketidakpuasan Dan Ketidakpercayaan Pasien}

$\begin{array}{ll}\text { Dokter tidak menyediakan waktu yang cukup untuk pasien } & 51 \% \\ \text { Dokter tidak ramah } & 42 \% \\ \text { Dokter tidak menjawab pertanyaan dengan jujur dan lengkap } & 42 \% \\ \text { Dokter kurang pengetahuan dan kurang kompeten } & 37 \% \\ \text { Penjelasan dokter tidak dimengerti } & 30 \% \\ \text { Dokter tidak memperlakukan pasien dengan hormat } & 27 \% \\ \text { Dokter tidak selalu berada di tempat bilamana diperlukan } & 27 \%\end{array}$

Sumber: Nazario, dalam Tubbs dan Moss, 2000

Memaknainya sebagai membingungkan karena tidak konsistennya informasi yang diterima dari seorang dokter dengan dokter yang lain, bahkan sampai menyalahkan tindakan yang telah dilakukan dokter lain. Makna membingungkan juga disebabkan oleh berlarut-larutnya penyakit tanpa kejelasan informasi tentang risiko penyakit, nama penyakit dan pengobatannya, bahkan ada dokter yang tidak memberi tindakan apapun karena dianggap salah tempat berobat. Makna informasi yang membingungkan tidak semata-mata datang dari informasinya, namun disebabkan oleh kemampuan individu dalam membentuk makna yang dihasilkan dari interaksinya dengan individu lain dalam lingkungannya. Menurut Sellnow dkk, (2009) people have widely varying capacities to process risk messages, including scientific and technical understandings of risk. Moreover, risk experts often view the public as obtuse, uninformed, ignorant, and hysterical about issues of risk and are dismissive of the public's ininformed concerns.

Penyandang filariasis yang sebagian besar berpendidikan tidak tamat SD memiliki keterbatasan interaksi sosial dengan dokter yang memiliki kekuasaan, status, dan kemampuan yang tinggi. Seperti yang dinyatakan oleh Tubbs dan Moss (2000), bahwa hubungan dokter-pasien adalah unik dan secara tradisional diatur oleh sejumlah norma yang berhubungan dengan kekuasaan, status, dan kemampuan. Dengan jarak sosial yang sangat jauh, penyandang filariasis mendefinisikan dan menampilkan dirinya sesuai dengan kesadaran dirinya dalam berinteraksi dengan dokter. Kesadaran adalah pemahaman manusia atas pengalamannya sendiri, yang memungkinkan mendefinisikan dirinya sendiri dan keadaannya. Kesadaran diri muncul ketika individu memasuki pengalaman dirinya sendiri sebagai suatu objek (Mead dalam Mulyana, 2004). Ketika berinteraksi dengan dokter, penyandang filariasis memasuki pengalaman dirinya yang sakit, cacat, berpendidikan rendah dan hal lainnya yang memengaruhi perilakunya sesuai dengan harapan orang lain, yaitu dokter. Perilakunya yang merupakan penafsiran tentang diri dari makna atas tindakan dokter menjadi tidak seimbang. Perilaku penyandang filariasis menjadi pasif karena definisi diri yang lebih rendah dibandingkan dengan dokter. Perilakunya yang pasif disebabkan karena penyandang filariasis takut atau malu untuk bertanya atau mendeskripsikan gejala sakitnya.

Dengan pertukaran informasi yang didominasi oleh peran dokter, informasi yang diperoleh penyandang filariasis tentang penyakitnya merupakan hasil dari komunikasi satu arah yang kurang dapat dipahami. 
Informasi yang kurang jelas membuat penyandang filariasis mengalami ketidak puasan dan ketidakpercayaan terhadap dokter sehingga mereka beralih ke dokter yang lain. Penelitian di Amerika mengenai berpindahnya pasien ke dokter lain karena ketidakpuasan dan ketidakpercayaan pasien, diketahui dengan alasan seperti terlihat pada tabel 1 .

Berpindahnya pasien dari dokter yang satu ke dokter yang lain tidak membuat informasi tentang penyakit filariasis menjadi jelas. Bagi sebagian besar penyandang filariasis, pemaknaan bahwa informasi yang didapatnya dari dokter tidak berubah yaitu membingungkan. Padahal menurut DiMatteo $\mathrm{dkk}$, effective communication has been shown to have positive impact on patient compliance to health recomendations, patient satisfaction, patient retention rates, overall health outcomes, and even a reduced number of malpractice suits (Sciavo,2007).

Namun demikian ada seorang penyandang filariasis yang memaknai informasi yang didapatnya dari dokter sebagai pembuat optimis, sehingga sampai saat ini masih menjalani pengobatan secara medis. Penyandang filariasis yang cukup terpandang di lingkungannya ini dapat mendefinisikan dirinya dalam pengalaman orang lain, sehingga dalam interaksinya dengan dokter tidak mengalami kebingungan informasi walaupun sering berpindah dokter untuk pengobatan yang dianggapnya lebih efektif.

\section{Makna Informasi Nama Penyakit}

Seperti yang telah dikemukakan sebelumnya, bahwa menurut bahasa atau terminologi kesehatan, penyakit yang disandang pasien adalah penyakit kaki gajah atau filariasis. Namun demikian fakta di lapangan menunjukkan bahwa penyandang filariasis memperoleh nama penyakit yang berbeda-beda dari dokter yang berbeda-beda. Penyakit filariasis dengan gejalanya yang sama telah dinamai berbeda-beda oleh dokter, yaitu leungeun gajah, penyumbatan darah bening, penyakit kelenjar, eksim gajah, infeksi sekunder, dan bahkan tidak disebutkan nama penyakitnya sama sekali.
Nama penyakit yang dapat dipahami oleh pasien adalah simbol. Jadi apapun nama penyakit sebagai pengganti nama filariasis, sepanjang dapat diterima oleh penyandang filariasis, maka nama itu adalah simbol. Menurut Mead, hanya apabila kita memiliki sismbol-simbol yang bermakna, kita berkomunikasi dalam arti yang sesungguhnya (Mulyana,2004). Dalam interaksi simbolik, simbol memiliki arti sebagai berikut:

1. Simbol adalah objek sosial.

Simbol diciptakan secara sosial, digunakan secara sengaja dalam situasi dan cara yang berbeda dan dipahami bersama.

2. Simbol itu mengandung makna.

Simbol dipahami bersama sebagai representasi dari sesuatu, bukan sekedar respon tetapi memiliki arti yang disepakati.

3. Simbol digunakan untuk merepresentasikan dan mengomunikasikan.

Simbol digunakan untuk merepresentasikan, pikiran, pengetahuan, perasaan dan diri kita kepada orang lain. Simbol juga digunakan untuk berkomunikasi dengan diri sendiri.

4. Simbol secara sengaja digunakan.

Simbol adalah tindakan sengaja dari komunikasi. Simbol harus membangkitkan respon yang sama pada pelaku komunikasi (Charon,2007).

Penamaan penyakit yang berbedabeda menjadi simbol yang dapat diterima begitu saja oleh para penyandang filariasis karena dianggapnya sesuai dengan presentasi diri mereka secara fisik. Namun demikian penamaan penyakit yang tidak seragam ini menimbulkan pertanyaan bagi peneliti sehubungan dengan penyandang filariasis yang menjadi subjek penelitian. Menurut Heath dan O'Hair, (2009) full disclosure of honest and accurate information can help built relationships and understanding in the risk communication context even when the information itself involves conflict or is not of a positive nature. Tidak terbuka, tidak terus terang, dan tidak jujurnya dokter dalam menyampaikan informasi risiko kepada penyandang filariasis membuat hubungan dokter - pasien tidak berkelanjutan. 
Penyandang filariasis diposisikan dan memosisikan dirinya sebagai objek komunikasi linear, kecuali bagi penyandang filariasis yang lebih baik pendidikannya. Penyebutan filariasis dengan nama yang berbeda-beda, walaupun kurang tepat dalam praktek komunikasi risiko kesehatan, dapat dijelaskan sbb:

1. Berkaitan dengan informasi risiko kesehatan, nama penyakit filariasis atau kaki gajah diketahui dokter sebagai penyakit yang menimbulkan cacat menetap yang tidak dapat disembuhkan yang dapat menular dan mewabah menjadi penyakit endemik. Penyampaian informasi risiko penyakit filariasis merupakan bagian dari komunikasi risiko kesehatan. Dokter adalah salah satu sumber informasi dalam komunikasi risiko kesehatan, selain lembaga-lembaga kesehatan, media dan akademisi/peneliti. Informasi nama penyakit menjadi hal yang harus dengan sangat hati-hati disampaikan oleh dokter kepada pasiennya. Sama halnya seperti ketika dokter menemukan indikasi penyakit flu burung atau flu babi pada pasiennya. Informasi yang disampaikan dengan sembarangan oleh seorang profesional di bidang kesehatan akan menimbulkan efek yang tidak diharapkan di dalam masyarakat. Penyebutan selain filariasis, seperti penyumbatan pembuluh darah atau penyakit kelenjar adalah upaya dokter untuk membuat pasien memahami penyakitnya dan menjadikannya pengetahuan. Heath dalam Sellnow dkk (2009) mengatakan bahwa without understanding, information is not knowledge. Penyebutan penyumbatan pembuluh darah dan penyakit kelenjar adalah upaya dokter yang tampaknya dimaksudkan untuk menyederhanakan nama penyakit atau menurunkan tingkat risiko dari penyakit yang sesungguhnya.

2. Bagi pasien yang berpendidikan tinggi dengan status sosial ekonomi yang baik, informasi tentang nama penyakit yang sesungguhnya seyogyanya disampaikan untuk upaya-upaya tindakan atau pengobatan yang tepat dan cepat. Namun lain halnya jika yang dihadapi adalah pasien yang kondisi pendidikan dan status sosial ekonomi yang rendah. Nama penyakit filariasis atau kaki gajah akan menjadi sesuatu hal yang baru dan asing bagi pasien. Untuk menyampaikan informasi risiko kesehatan diperlukan kemampuan dokter dalam memahami frame of reference dari pasien, sehingga pasien dapat menerima informasi dengan lebih baik. Menurut Karasz, McKee dan Roybal dalam Heath dan O'Hair, (2009) people try to make sense of the world around them by integrating new information with existing beliefs. If those old beliefs are erroneous or confused, new information may be hard to process. Dengan penyebutan nama penyakit yang sesuai dengan pengalaman dan pemahaman pasien secara kasat mata mengenai penyakitnya, seperti leungeun gajah atau eksim gajah, diharapkan penyandang filariasis dapat menerima dan memahami penyakit ini dengan lebih baik. Namun demikian ada pula dokter yang tidak memberi penjelasan tentang nama penyakit kepada penyandang filariasis. Dari tinjauan komunikasi risiko kesehatan, hal ini dapat dipahami untuk menghindarkan kemarahan, kecemasan, frustasi dan kebencian dari pasien dan keluarganya terhadap petugas kesehatan (Lundgren dan McMakin, 2004).

3. Penyebutan nama penyakit yang berbeda dengan nama penyakit yang sesungguhnya dapat dibenarkan sepanjang nama lain dari penyakit itu menjadi simbol yang memiliki makna, yaitu bila simbol itu dapat membangkitkan individu yang menyampaikannya respon yang sama seperti juga yang akan muncul pada individu yang dituju (Mulyana, 2004). Leungeun gajah adalah simbol bahasa yang berupa kata yang memiliki makna yang jelas, yaitu tangan yang besar seperti tangan/kaki gajah. Begitu pula dengan eksim gajah, yang menunjukkan luka eksim pada bagian tubuh (kaki) yang bengkak seperti gajah. Dengan penyebutan nama penyakit tersebut, baik 
dokter maupun pasien secara bersamaan memaknai obyek fisik dengan pemaknaan yang sama.

4. Interaksi dokter dan pasien bergantung pada bagaimana mereka mendefinisikan situasi yang dihadapi. Keduanya dipandang aktif untuk menentukan lingkungan mereka sendiri. Makna nama penyakit tidak melekat pada objek, melainkan dinegosiasikan melalui penggunaan bahasa. Ketika dokter dengan keahliannya mendefinisikan dirinya berkuasa berhadapan dengan pasien sebagai objek fisik yang lemah, maka dokter menegosiasikan makna melalui penggunaan bahasa yang sembarang. Artinya bahwa dokter bisa saja menggunakan kata apapun sebagai pengganti kata filariasis sepanjang makna dimaksud sesuai dengan yang dapat dipahami pasien.

\section{Makna Informasi Filariasis dari Media Massa}

Dalam menyebarluaskan informasi risiko, media massa memegang peranan yang sangat besar. Informasi tentang filariasis merebak sejak Program Pengobatan Filariasis dicanangkan di seluruh Kabupaten Bandung, terutama setelah peristiwa tewasnya sembilan warga yang diduga akibat pengobatan massal. Informasi mengenai pengobatan massal dan dampaknya bagi sebagian warga yang meminumnya, baik bagi korban yang meninggal maupun yang mengalami efek samping dari obat telah diliput oleh berbagai media baik cetak maupun elektronik.

Penggunaan televisi sebagai media hiburan dan informasi sangat sesuai bagi penyandang filariasis yang berada di perdesaan. Dengan karakteristiknya yang audio visual, khalayak tidak dituntut membayangkan narasi yang dibacakan seperti di radio, karena narasi sudah dilengkapi dengan visualisasinya. Oleh karena itu televisi memberi lebih banyak kemudahan bagi khalayaknya dalam menginterpretasikan informasi yang diterimanya. Namun demikian, ternyata mereka tidak merasakan manfaat dari pemberitaan tersebut. Sebagian besar dari penyandang filariasis memberi makna yang negatif terhadap pemberitaan tentang filariasis, yaitu menakut-nakuti, tidak penting, dan kurang berpengaruh. Hanya seorang saja yang memaknai informasi dari televisi dapat dipercaya ketika ditunjang oleh informasi yang sama dari media cetak.

Pemberitaan melalui media cetak seperti surat kabar pada umumnya tidak begitu diminati, hal ini sesuai dengan karakteristik media cetak yang menuntut kemampuan baca dari khalayaknya. Sedangkan media elektronik seperti radio juga kurang diminati karena dianggap tidak menarik. Penggunaan poster untuk penyebar luasan informasi risiko filariasis juga kurang mendapat perhatian penyandang filariasis, karena hanya dapat diakses di tempat tertentu seperti Rumah Sakit dan Puskesmas. Seorang penyandang filariasis yang mengetahui mengenai poster ini menyatakan ketidak tertarikannya dengan sambil lalu mengatakan ageung (besar). Hal ini dimaksudkan pada ilustrasi gambar dalam poster yang menampilkan bagian tubuh yang membengkak para penyandang filariasis.

Informasi yang disampaikan media massa tentang pengobatan massal dan jatuhnya beberapa korban tewas merupakan bentuk peranan media massa dalam komunikasi risiko kesehatan. Menurut Lundgren dan McMakin, (2004) media massa dapat memilih tingkat peranan yang diinginkannya sehubungan dengan isu-isu risiko, yaitu:

\section{Reporting existing information}

2. Influencing the way an issue is portrayed

3. Independently bringing an issue to the public's attention or restricting its coverage

4. Proposing solutions to a risk-related decision, including taking a stand on an issue.

Mengamati beberapa pemberitaan tentang pengobatan massal filariasis, dapat disimpulkan bahwa media massa telah memainkan peranannya sampai ke tingkat yang keempat dimana media tidak saja melaporkan, namun juga memengaruhi, 
menggiring perhatian publik dan pada akhirnya menawarkan solusi serta mengambil sikap terhadap isu pengobatan massal. Peran media yang lebih besar, yaitu ikut terlibat di dalam bersikap terhadap isu menunjukkan tingkat risiko yang dihadapi dalam masalah ini.

Namun demikian keterlibatan media dalam isu risiko kesehatan dan lingkungan seringkali dianggap oleh ilmuwan dan pengambil kebijakan sebagai terlalu sederhana, tidak akurat dan sensasional (Lundgren dan McMakin, 2004). Anggapan ini muncul karena adanya perbedaan "budaya" antara media massa dan peneliti atau pihak lain yang terkait risiko. Menurut Lundgren dan McMakin (2004) perbedaan budaya yang dimaksud adalah:

1. Media berfokus pada peristiwa, sehingga tidak memberi penjelasan yang utuh mengenai kemungkinan lain dengan kondisi yang lain, dan memperluas cakupan sosial maupun kebijakan dan informasi dengan konteks lainnya.

2. Media meliput isu risiko tertentu lebih banyak, padahal isu risiko yang dialami orang sehari-hari jauh lebih besar namun tidak mendapat liputan yang banyak.

3. Jurnalis yang independen dan deadline berita memengaruhi konten media sehingga media akan memberitakan isu risiko sesuai pengetahuannya dan berita menjadi terbatas sumbernya.

4. Berita media dipadatkan, disederhanakan dan dipersonalisasikan karena terbatasnya pengetahuan ilmiah dan teknologi para jurnalis, serta terbatasnya ruang dan waktu yang disediakan media. Pemberitaan akibat risiko secara personal ditujukan untuk menarik perhatian khalayak, namun biasanya berakibat tidak lengkapnya informasi dan tidak seimbangnya informasi untuk keputusan risiko yang tepat.

Merujuk pada pendapat di atas, dapat dipahami pemaknaan yang muncul akibat informasi yang diperoleh penyandang filariasis melalui media massa. Makna menakut-nakuti dinyatakan oleh penyandang filariasis karena media televisi terlalu banyak menayangkan cacat tubuh yang berupa bengkak pada beberapa penyandang filariasis. Penayangan cacat tubuh, sesuai dengan budaya media yang sensasional, yaitu yang mudah menarik perhatian khalayak tanpa memperhitungkan khalayak penyandang filariasis yang juga menjadi khalayaknya. Penayangan kisah atau pengalaman personal dengan menonjolkan cacat tubuh juga sesuai dengan budaya personalisasi dari media untuk menarik perhatian khalayak.

Pemberitaan televisi yang mengekspos cacat tubuh akibat filariasis berdampak pada penyandang filariasis yang merasa ditakuttakuti. Gambaran diri sebagai penyandang filariasis dihadirkan di layar kaca dengan narasi yang membangkitkan perasaan sedih yang selama ini dikuburnya dalam-dalam. Berdasarkan pengalaman sakitnya, mereka telah sejak lama mendefinisikan dirinya sebagai obyek sosial yang menyandang filariasis. Namun seiring berjalannya waktu, mereka merasa diterima lingkungannya dan dapat beraktivitas layaknya orang normal sehingga melupakan definisi diri yang sesungguhnya. Dengan penayangan gambaran diri melalui televisi, kepercayaan dirinya tergoyahkan karena menyadari dirinya tidak normal karena cacat yang disandangnya.

Informasi melalui media juga ada yang memaknainya sebagai kurang penting dan tidak berpengaruh. Bagi penyandang filariasis yang mengalami sakit yang panjang dan mengalami cacat sepanjang hidupnya, informasi melalui media ini hampir tidak bermakna. Pengalaman sakit dengan upaya pengobatan yang tidak membuahkan hasil telah membawa penyandang filariasis pada sebuah keyakinan bahwa mereka harus menerima dan pasrah dengan keadaannya. Sedangkan bagi yang memaknai informasi melalui media sebagai dapat dipercaya, karena penyandang filariasis ini mengalami cacat akibat filariasis sejak bayi sehingga dapat menerima kondisi diri dengan lebih baik sehingga dapat menerima informasi dari media dengan lebih terbuka. 


\section{PENUTUP}

\section{Simpulan}

Berdasarkan pembahasan yang telah disajikan, dapat ditarik beberapa simpulan sebagai berikut:

Informasi risiko penyakit filariasis yang diterima dari dokter dimaknai oleh sebagian besar penyandang filariasis sebagai menakutnakuti dan membingungkan, meskipun ada yang memaknainya sebagai terpercaya dan membuat optimis.

Informasi risiko filariasis yang tidak akurat tercermin dari penamaan penyakit filariasis oleh dokter dengan sebutan yang berbeda-beda yaitu leungeun gajah, eksim gajah, penyakit kelenjar dan infeksi sekunder.

Informasi risiko melalui media massa televisi yang cenderung berlebihan dimaknai melalui surat kabar.

\section{Saran}

Rendahnya literasi kesehatan dan keterampilan dalam berkomunikasi yang mengakibatkan rendahnya pengetahuan dan pemahaman penyandang filariasis terhadap informasi kesehatan sebaiknya disikapi oleh penyelenggara kesehatan dengan disediakannya pendampingan bagi pasien yang memerlukan bantuan pemeriksaan ataupun pengobatan.

Dokter-dokter di daerah sebaiknya diberikan pelatihan komunikasi efektif dokter dengan pasien, yang mengedepankan kepentingan pasien. Melayani pasien dengan literasi kesehatan yang rendah memerlukan upaya peningkatan kemampuan dokter dalam berkomunikasi untuk dapat lebih berempati terhadap kondisi sosial ekonomi dan budaya pasien.

Peran media massa yang strategis dalam penyebarluasan informasi sebaiknya dijadikan mitra sejajar Dinas Kesehatan atau Kementerian Kesehatan. Dinkes atau Kemenkes dan media massa sebaiknya samasama memahami bahwa Program Pengobatan Massal Filariasis termasuk ke dalam ranah informasi komunikasi risiko kesehatan. Pemahaman yang kurang terhadap konsep komunikasi risiko akan berakibat pada sosialisasi atau pemberitaan informasi risiko kesehatan yang dampaknya tidak sesuai dengan harapan.

Penggunaan media dalam penyebar luasan informasi kesehatan seperti, poster, spanduk, brosur dan yang sejenisnya sebaiknya mempertimbangkan faktor bahasa, pemilihan kata, penyajian gambar dan lokasi media informasi itu ditempelkan,dipasang atau dibagikan. Kesalahan berkenaan dengan faktor-fator tersebut dapat berakibat tidak efektifnya pesan yang ingin disampaikan. Jika diperlukan, jalin kerjasama dengan pihak lain untuk merancang media komunikasi kesehatan yang lebih efektif dan efisien.

\section{DAFTAR PUSTAKA}

Charon, Joel M. (2007) Symbolic Interactionism, an Introduction, an Interpretation, an Integration. London: Prentice-Hall.Inc.

Covello D. and P. Slovic. (1986) Risk Communication: a Review of the Literature. Washington DC.

Creswell, John W. (1998) Qualitative Inquiry and Research Design:Choosing Among Five Approaches. Thousand Oaks, CA: Sage Publication Inc.

Heath, R. L and O'Hair H.D. (2009) Handbook of Risk and Crisis Communication. NY: Routledge.

Littlejohn, Stephen W. (2005) Theories of Human Communication, eigth edition. Belmont California: Wadsworth Publishing Company.

Lundgren R, McMackin A. (2004) Risk Communication: A Handbook for Communicating Environtmental, Safety, and Health Risks, Third Edition. Columbus, Ohio: Battelle Press.

Mulyana, Deddy. (2004) Ilmu Komunikasi. Suatu Pengantar. Bandung: Remaja Rosdakarya.

Powell, D. and W. Leiss. (2001) Mad Cows 
And Mother's Milk: The Perils of Poor Risks Communication. Canada: McGill - Queen's University Press.

Schiavo, Renata. (2007) Health

Communication From Theory to Practice. CA: Jossey - Bass.

Sellnow T.L., Ulmer R.R, Seeger M.W. and Littlefield R.S. (2009) Effective Risk

Communication: A Message-

Centered Approach. New York: Springer.

Thompson, Teresa L.Aliccia M. Dorcey, KatherineI. Miller and Roxanne Parrot. (2003) Handbook of Health Communication. Lawrence Erlbaum Associates Publishers, NJ

Tubbs S.L. and Moss S. (2000) Human Communication, Konteks-Konteks Komunikasi Terjemahan Deddy Mulyana. Bandung: PT Remaja Rosdakarya. 